\title{
Protein conjugated with aldehydes derived from lipid peroxidation as an independent parameter of the carbonyl stress in the kidney damage
}

\author{
Rafael Medina-Navarro ${ }^{1 *}$, Renato Nieto-Aguilar ${ }^{1,3}$ and Cleto Alvares-Aguilar ${ }^{2}$
}

\begin{abstract}
Background: One of the well-defined and characterized protein modifications usually produced by oxidation is carbonylation, an irreversible non-enzymatic modification of proteins. However, carbonyl groups can be introduced into proteins by non-oxidative mechanisms. Reactive carbonyl compounds have been observed to have increased in patients with renal failure. In the present work we have described a procedure designed as aldehyde capture to calculate the protein carbonyl stress derived solely from lipid peroxidation.

Methods: Acrolein-albumin adduct was prepared as standard at alkaline pH. Rat liver microsomal membranes and serum samples from patients with diabetic nephropathy were subjected to the aldehyde capture procedure and aldol-protein formation. Before alkalinization and incubation, samples were precipitated and redisolved in $6 \mathrm{M}$ guanidine. The absorbances of the samples were read with a spectrophotometer at $266 \mathrm{~nm}$ against a blank of guanidine.

Results: Evidence showed abundance of unsaturated aldehydes derived from lipid peroxidation in rat liver microsomal membranes and in the serum of diabetic patients with advanced chronic kidney disease. Carbonyl protein and aldol-proteins resulted higher in the diabetic nephropathy patients $(p<0.004$ and $p<0.0001$ respectively).

Conclusion: The aldehyde-protein adduct represents a non oxidative component of carbonyl stress, independent of the direct amino acid oxidation and could constitute a practical and novelty strategy to measure the carbonyl stress derived solely from lipid peroxidation and particularly in diabetic nephropathy patients. In addition, we are in a position to propose an alternative explanation of why alkalinization of urine attenuates rhabdomyolysis-induced renal dysfunction.
\end{abstract}

Keywords: fatty acids lipid peroxidation, protein carbonyl, unsaturated aldehydes, renal failure, rhabdomyolysis

\section{Background}

Oxidation can cause proteins to suffer loss of catalytic function, degradation, proteolysis and several degrees of denaturation $[1,2]$. Protein oxidation increases during aging and has been consistently associated with many pathologies such as diabetes, atherosclerosis, cataracts, renal damage, and more $[3,4]$. One of the well-defined and characterized protein modifications usually produced by oxidation is carbonylation, an irreversible non-

\footnotetext{
* Correspondence: rafael.medina@imss.gob.mx

'Department of Experimental Metabolism. Center for Biomedical Research of Michoacán (CIBIMI-IMSS), Michoacán, México

Full list of author information is available at the end of the article
}

enzymatic modification of proteins [5]. Therefore, oxidation of protein can be measured by the addition of carbonyl groups. The spectrophotometric assay using 2, 4dinitrophenylhydrazine (DNPH) constitutes one of the primary ways of detecting carbonyls, since it is relatively easy, fast and inexpensive [6,7]. Carbonyl groups are introduced into proteins by metal-catalyzed oxidation and a variety of reactive nitrogen species (nitric oxide, peroxinitrite), reactive chlorine species (hypochlorous acid, nitryl chloride) and reactive oxygen species (hydrogen peroxide, hydroxyl radical, peroxiradicals, ozone, etc. $[8-10]$.

\section{C) Biomed Central}


However, carbonyl groups can be introduced into proteins by non-oxidative mechanisms, and this can increase carbonyl levels in proteins in an extensive manner. Carbonyl groups can be introduced into proteins by reaction with molecules such as acrolein, 4-hydroxy-2nonenal (HNE) and other alpha-beta unsaturated aldehydes derived from lipid peroxidation that react with protein residues via several kinds of reactions, included Schiff base formation and Michael addition reactions [11]. Hence, the presence of carbonyl is not necessarily indicative of direct oxidation of amino acid residues in proteins, and the importance of lipid peroxidation and the participation of reactive low molecular weight aldehydes on protein carbonylation have been demonstrated [12-14].

Reactive carbonyl compounds derived from lipids and carbohydrates by both oxidative and non-oxidative routes have been observed to have increased in patients with renal damage. These compounds react with proteins, resulting in the condition described as "carbonyl stress", which underlies the development of uremic complications [15]. Uremic plasma contains elevated levels of low weight molecular carbonyl compounds [16]. These do not seem to be secondary products of protein glycation nor do they depend on glucose plasma concentration, but more probably are reactive carbonyl compounds derived from carbohydrates, lipids and amino acids $[16,17]$. Rhabdomyolisis with extensive muscle release of myoglobyn $(\mathrm{Mb})$ generates kidney damage caused by redox cycling of the heme radicals [18]. Lipid peroxidation catalyzed by the hemoprotein's radicals is probably the more documented explanation for the oxidative damage associated with rhabdomyolysis [19], and this condition constitutes another potential source of the alpha beta unsaturated aldehydes and carbonyl stress in the kidney.

Proteins have an enormous capability to conjugate with alpha-betha unsaturated aldehydes. At alkaline pH albumin isomerizes and exposes cysteine thiolate anions. Previous research indicates that the highly nucleophilic thiolate state is the adduct target for the alfa, beta-unsaturated carbonyl compounds [20-22]. We found that, in addition to the described reactions, unsaturated aldehydes at alkaline $\mathrm{pH}$ can undergo aldolic condensation linked to the proteins and form stable adducts with corresponding increases in absorbance at $266 \mathrm{~nm}$. Taking advantage of properties mentioned we implement a simple procedure to calculate the abundance of these compounds from a sample containing proteins such as serum or plasma (aldehyde capture).

We observed an intense aldehyde capture during the rat liver microsomal peroxidation catalyzed by NADPH, demonstrating the participation of membranes fatty acids phospholipids as the source of alpha beta unsaturated aldehydes. Then, serum samples were subjected to the aldehyde capture and the results permitted us to corroborate the alpha-beta unsaturated aldehydedependent carbonyl stress derived from lipid peroxidation in the serum of diabetic patients with advanced chronic kidney disease.

\section{Results}

Acrolein condensation proceeds even with protein linked (aldehyde capture)

The kinetic of the aldehyde condensation in an alkalicatalyzed aldol reaction can be observed in Figure 1 (scan and bars 0 to 5). Acrolein in the presence of albumin polymerized $(266 \mathrm{~nm})$ in their bulk solution in a time dependent manner (0-50 minutes). A second independent peak can be observed at $280 \mathrm{~nm}$ (Figure 1 scan, line 1) and corresponds to the intrinsic absorbance of the albumin, which does not change with respect to time. The same strong absorbance of aldehyde at 266 $\mathrm{nm}$ in fatty acids protein-free solutions can be presented (Additional File 1) and follows a similar reaction kinetic, as been observed elsewhere [23,24]. Increasing amounts of acrolein-albumin adduct (aldol-proteins) were used to perform standard curves, one of which is presented in Figure 2. The slopes of each curve are determined by differences in absorbance at $266 \mathrm{~nm}$ in relation with adduct concentration. This way the average slope values

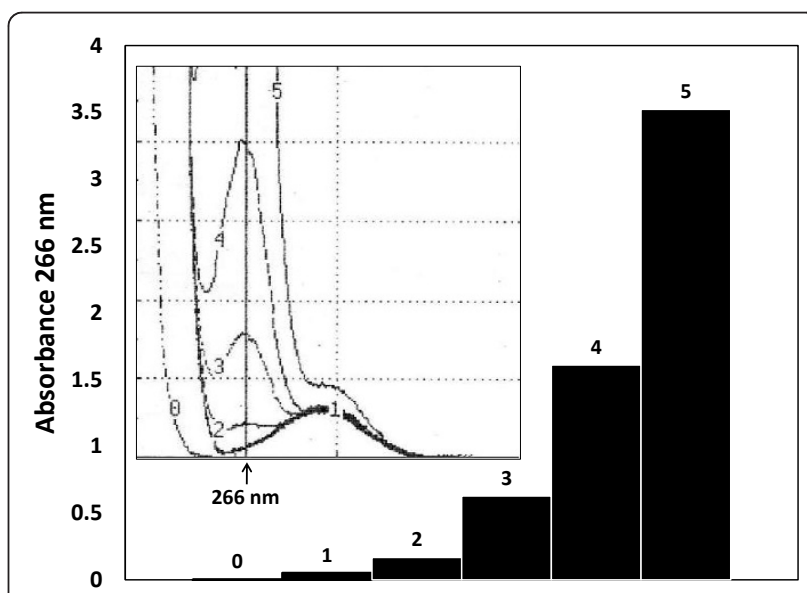

Figure 1 Spectral scans and the kinetic of aldol-protein formation with respect to the time. At the internal graph, aldehyde condensation of acrolein in the presence of albumin at alkaline $\mathrm{pH}$ proceeds from 0 to 50 minutes (number $0-5$ on the line), making grow the absorbance denoted by ascending peaks at $266 \mathrm{~nm}$. One more peak, corresponding to protein absorbance is showing around $280 \mathrm{~nm}$ but this time without apparent time dependent changes. At right side the bars denoting the exponential behave corresponding to the protein-aldehyde condensation kinetic. The data depicted correspond to one of the curves obtained using the described experimental conditions such as was explained in material and method section. 


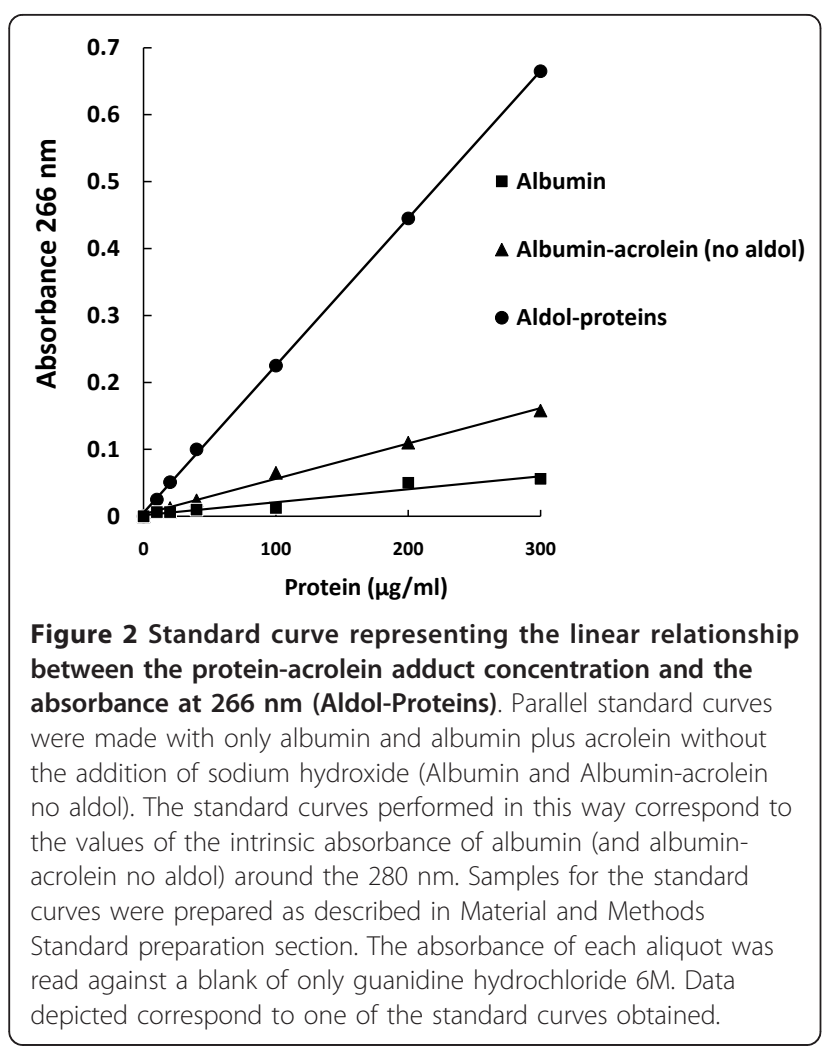

of the two principal curves were 1851 and 411 for the Albumin-acrolein no aldol and the aldol-protein respectively. Some no catalyzed aldehyde captures and then spontaneous aldol-protein formation can be observed (Albumin-acrolein (no aldol) cuerve).

\section{Aldol-protein formation in the catalyzed microsomal peroxidation and its inhibition with bisulfite}

The products of catalyzed microsomal peroxidation increase the absorbance of the control sample at $266 \mathrm{~nm}$ by a factor of more than 14 (Figure 3 , \#1 vs. \#3). Protein presented in the reaction mixture corresponds exclusively to the membrane proteins, and then the product obtained after sample precipitation corresponds to the aldol-proteins. When sodium bisulfite was added at the end of the incubation period of peroxidation, the absorbance fell (Figure 3, \#4), (p < 0.0001) and reached values close to its control. Even in the control case (MICROSOMES NO PEROXIDATION), a fall of the initial amount could be observed (Figure $3 \# 2$; p < 0.01) with the addition of bisulfite. Bisulfite interferes directly with carbonyl groups derived from aldehydes in the aldolic condensation.

\section{Protein carbonyl and Aldol-proteins in serum samples from patients with diabetic nephropathy}

Table 1 summarizes the aldol-protein and protein carbonyl content of serum samples of 21 healthy subjects

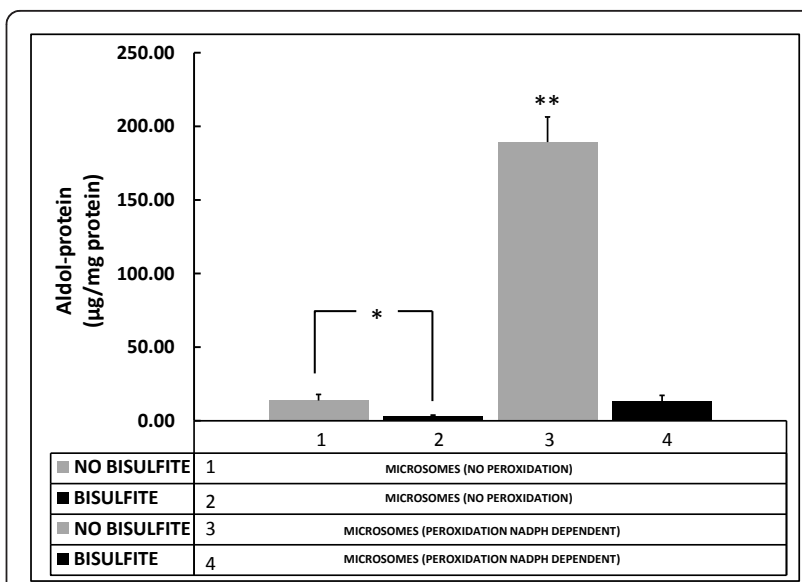

Figure 3 Aldol-proteins formation in the NADPH-dependent microsomal peroxidation. The products of catalyzed microsomal peroxidation increase the absorbance of the control sample at 266 $\mathrm{nm}$ by a factor of more than 14 (Bars \#1 vs. \#3). When sodium bisulfite was added at the end of the incubation period of peroxidation, the absorbance fell (Figure 3, \#4), and reached values close to its control. Even in the control case, a fall of the initial amount could be observed with the addition of bisulfite (Bars \#1 vs. \#2). Bisulfite interferes directly with carbonyl groups derived from aldehydes in the aldolic condensation. ${ }^{*} p<0.01 ;{ }^{*} p<0.0001$ compared with all the other groups.

and 18 patients with diabetic nephropathy. All the patients have a GFR in the range $16-45 \mathrm{ml} / \mathrm{min} / 1.73 \mathrm{~m}^{3}$ and chronic stage 3-4 kidney disease (moderate to severe GFR reduction); meanwhile the healthy volunteers presented a GFR $>90 \mathrm{ml} / \mathrm{min} / 1.73 \mathrm{~m}^{3}$, calculated from creatinine concentration and the Cockroft-Gault formula [25]. Carbonyl protein and aldol-proteins resulted higher in the diabetic nephropathy patients $(\mathrm{p}<$ 0.004 and $\mathrm{p}<0.0001$ respectively). Introduction of carbonyl groups to the serum sample proteins after aldehyde capture corroborated the aldehyde incorporation $(\mathrm{p}<0.002)$ (A comparative graph is presented in Additional file 2).

Table 1 Amount of the protein carbonyls and aldolproteins in serum samples

\begin{tabular}{lccc}
\hline & $\begin{array}{c}\text { Control } \\
\text { group } \\
\mathbf{n = 2 1}\end{array}$ & $\begin{array}{c}\text { Diabetic } \\
\text { Nephropathy } \\
\mathbf{n}=\mathbf{1 8}\end{array}$ & $\begin{array}{c}\mathbf{p} \\
\text { value }\end{array}$ \\
\hline $\begin{array}{l}\text { Carbonyl protein } \\
\text { (nmol/mg of protein) }\end{array}$ & $1.17 \pm 0.32$ & $1.74 \pm 0.54$ & 0.004 \\
$\begin{array}{l}\text { Aldol-proteins } \\
\text { ( } \mathrm{Mg} / \mathrm{mg} \text { of protein) }\end{array}$ & $106.75 \pm 5.7$ & $123.35 \pm 14.9$ & 0.0001 \\
$\begin{array}{l}\text { Carbonyl protein } \\
\text { after aldehyde }\end{array}$ & $1.09 \pm 0.17$ & $3.24 \pm 0.55$ & 0.002 \\
$\begin{array}{l}\text { capture } \\
(\mathrm{nmol} / \mathrm{mg} \text { of protein) }\end{array}$ & & & \\
$\begin{array}{l}\text { GFR* } \\
\left(\mathrm{ml} / \mathrm{min} / 1.73 \mathrm{~m}^{2}\right)\end{array}$ & $90.9 \pm 5.3$ & $30.4 \pm 14.3$ & 0.00002 \\
\hline
\end{tabular}

*Glomerular Filtration Rate 


\section{Discussion}

In the present work we have described a procedure to calculate the protein carbonyl content derived from unsaturated aldehydes, by the use of changes experimented by the albumin molecule at alkaline $\mathrm{pH}$. Formation of stable adducts or aldol-proteins in serum samples constitute a practical and novelty strategy to measure the carbonyl stress derived from lipid peroxidation.

Lipid peroxidation is one of the principal outcomes of carbonyl stress damage to biological components. The most abundant products of lipid peroxidation are aldehydes such as acrolein, malondialdehyde (MDA), 4hydroxy-2-nonenal (HNE) and 4-hydroxy-2-hexenal (HHE), and are frequently measured as indicators of lipid peroxidation [26]. Conjugated diene measurement is useful in studies of pure lipids and it measures an early stage in the peroxidation process [27]. The measurement of malondialdehyde (MDA) by the thiobarbituric acid reactive substances assay (TBARS) is generally not a good method when applied to biological samples, although it has been widely utilized in the past [28]. These compounds and some others like isoprostanes are all measurable in biological fluids but the analytical methods used turned out to be complex and require sample preparation involving extraction and purification steps [29].

In the present work, we calculated the abundance of alpha beta unsaturated aldehydes in the plasma of diabetic patients with and without renal damage. We used a simple procedure to calculate the content of aldehydes captured by serum proteins. First we used microsomal membranes to demonstrate the aldehyde condensationdependent absorbance increase at $266 \mathrm{~nm}$ and the plausible protein-dependent aldehyde capture. The aldehyde incorporation to proteins appears as independent component of carbonyl stress in serum of diabetic nephropathy patients. The aldehyde incorporation was abolished in the microsomal peroxidation NADPHdependent through the use of sodium bisulfite, an efficient nuclephile agent that removes aldehyde groups by attacking the carbon atom of the carbonyl group. Additionally, the intense aldehyde-capture derived from the microsomal peroxidation helps us to find the source of these particular aldehydes in the unsaturated fatty acids derived from membrane phospholipids.

The oxidation of biomolecules such as carbohydrates and lipids and/or the inadequate detoxification of carbonyl compounds may contribute to the progression of complications of end-stage renal disease [30]. A better understanding of the nature of carbonyl stress in diabetic glomerular lesions would help in the search for novel approaches to confront diabetic renal damage. Additionally, if the generation of reactive carbonyl compounds is not only secondary to oxidative stress but also an active contributor to the renal disease pathogenesis, as has been suggested [31,32], an inhibition of protein carbonylation reaction might be relevant, and the approaches to measuring the aldehydes abundance might be very useful in the development of new treatment strategies.

From the results obtained we can corroborate the importance of unsaturated aldehydes in the uremic plasma as an independent parameter of carbonyl stress. In addition, we are in a position to propose an alternative explanation of why alkalinization of urine attenuates rhabdomyolysis-induced renal dysfunction [33-35]. Although one acceptable explanation is that alkalinization enhances the myoglobin ( $\mathrm{Mb})$ solubility [34] and that lipid peroxidation reactions are accelerated at acidic $\mathrm{pH}[35,36]$, a plausible alternative can be deduced from data presented here, suggesting that alpha-beta-unsaturated compounds condensation catalyzed at alkaline $\mathrm{pH}$ could reduce renal dysfunctions during rabdomyolisis. It is possible to suppose that polymerization of reactive aldehydes represents a way to block carbonyl groups in large amounts and promote carbonyl stress amelioration.

\section{Materials and methods}

Unless noted otherwise, biochemicals were obtained from Sigma Chemical Co., St. Louis, MO; albumin from bovine serum (BSA) (fraction V, lyophilized powder 98\%); albumin from human serum (lyophilized powder 99\%); 2, 4-dinitrophenylhydrazine (DNPH); ethylenediaminetetraacetic acid (EDTA); guanidine hydrochloride; acrolein (2-propenal) 99\%, sodium bisulfite (sodium hydrogensulfite $\geq 99 \%$ ) and sodium hydroxide (Sigma Ultra 98\%); nicotinamide; adenosine 5'- diphosphate sodium salt (ADP), ferric Chloride $\left(\mathrm{FeCl}_{3}\right)$ and $\beta$-Nicotinamide adenine dinucleotide phosphate reduced form ( $\beta$-NADPH).

\section{Samples}

Serum aliquots of diabetic patients of the Unit of Nephrology at General Hospital \# 80 of the Mexican Institute of Social Security, Morelia, Michoacán, México were collected from samples that were used in the periodic clinical examinations. Control serum samples were collected from individuals recruited for blood donations. All patients received and gave both oral and written informed consent for the use of the aliquot samples. Blood samples were obtained in the morning after fasting by venipuncture in tubes without anticoagulant. Serum (21 controls and 18 diabetic with nephropathy) was stored at $-30^{\circ} \mathrm{C}$ and in all cases was used 3 days after being collected. Animal samples. Hepatic tissue from Sprague Dowley male rats weighing 200-250 g was used. Animal procedures and management were made 
in accordance with the National Institute of Health Guide for the Care and Use of Laboratory Animals and approved by the Ethics Committee of the Mexican Institute of Social Security.

\section{Acrolein capture by albumin and protein adducts (Aldol- proteins) measurement}

Standard preparation. An adduct acrolein-albumin standard curve was prepared as follows: $5 \mathrm{mg}$ of human or bovine serum albumin was dissolved completely in $5 \mathrm{ml}$ PBS and then incubated at room temperature with acrolein $(10 \mu \mathrm{M}$ final concentration), $100 \mu \mathrm{l}$ of $0.01 \mathrm{mM}$ EDTA and $100 \mu \mathrm{l}$ of a $1 \%$ sodium hydroxide solution. Aldolic condensates were formed this way in a time dependent manner (Figure 1). The reaction mixture was neutralized with HCL $(2 \mathrm{~N})$ and dialyzed overnight against $\mathrm{PBS}$ at $4^{\circ} \mathrm{C}$. Aliquots containing increasing amounts of protein were precipitated using $30 \% \mathrm{ZnSO}_{4}$ and centrifuged 15 minutes at 5, $000 \mathrm{~g}$; the pellets were dissolved with $6 \mathrm{M}$ guanidine hydrochloride and incubated at $37^{\circ} \mathrm{C}$ for 2 hours with occasional vortex mixing. The absorbance of each aliquot was read with a spectrophotometer at $266 \mathrm{~nm}$ (aldolic condensation) against a blank of only guanidine hydrochloride $6 \mathrm{M}$. The standard curve performed represents the linear relationship between the protein-acrolein adducts concentration or aldol-protein abundance and the absorbance at $266 \mathrm{~nm}$ (Figure 2, aldol-protein). Different alpha-beta unsaturated incubated with albumin and aldehydes in proteinfree solutions present strong absorbance at $266 \mathrm{~nm}$, although acrolein showed the maximal efficiency in adduct formation $[27,28]$.

Parallel standard curves were made in the same conditions with only albumin and albumin plus acrolein without the addition of sodium hydroxide (Figure 2, albumin and albumin plus acrolein). The standard curves performed in this way correspond to the indirect absorbance of albumin (and albumin plus acrolein) at $266 \mathrm{~nm}$, as a consequence of its intrinsic absorbance at $280 \mathrm{~nm}$.

Sample procedure. Serum samples $(15 \mu \mathrm{l})$ dissolved in $50 \mu \mathrm{l}$ of PBS, $25 \mu \mathrm{l}$ of $0.1 \mathrm{mM}$ EDTA and $50 \mu \mathrm{l}$ of $1 \%$ sodium hydroxide were incubated for 20 minutes at $37^{\circ}$ C. At the end of incubation, samples were precipitated with $50 \mu \mathrm{l}$ of $\mathrm{ZnSO}_{4} 30 \%$, dissolved with an additional $500 \mu \mathrm{l}$ of PBS and centrifuged for 15 minutes at $5000 \mathrm{~g}$. Pellets were washed two more times with $0.5 \mathrm{ml}$ of PBS and finally dissolved with $6 \mathrm{M}$ guanidine hydrochloride and incubated at $37^{\circ} \mathrm{C}$ for 2 hours with occasional vortex mixing. The absorbances of the samples were read with a spectrophotometer at $266 \mathrm{~nm}$ against a blank of only guanidine hydrochloride $6 \mathrm{M}$, as explained previously.

Protein concentration was determined by the Bradford reagent and then the concentration used of each sample was adjusted with PBS. To the final concentration of protein in guanidine, standard curves of Bradford procedure were carried out substituting the vehicle by guanidine $2 \mathrm{M}$ and taking aliquot of $10 \mu \mathrm{l}$ of protein guanidine samples.

Using the absorbances of $266 \mathrm{~nm}$ and the slopes of the standard curves described previously (Figure 2) the Aldol-Protein concentration can be calculated as follows:

Aldol-Protein $=($ Abs $266 \mathrm{~nm}-\mathrm{F})(\mathrm{N} 2)$, where F is the calculated absorbance of albumin + acrolein mix (no aldol) at $266 \mathrm{~nm}$ and $\mathrm{N} 2$ corresponds to the slope of the aldol-protein adduct standard curve.

$\mathrm{F}=($ Abs $266 \mathrm{~nm})(\mathrm{N} 1)-($ Abs $266 \mathrm{~nm})(\mathrm{N} 2) /(\mathrm{N} 1)$, where $\mathrm{N} 1$ and $\mathrm{N} 2$ are the slopes of the standard curves of albumin + acrolein mix (no aldol) and aldol-protein respectively (1851 and 411 for the standard curves presented in Figure 2)

\section{Microsomal peroxidation catalyzed by NADPH}

Microsomes. Hepatic tissue from Sprague Dowley rats was homogenized in $25 \mathrm{M}$ sucrose. The homogenate was placed in a centrifuge tube and an equivalent volume of $0.34 \mathrm{M}$ sucrose was layered underneath. The discontinuous gradient thus formed was centrifuged for 10 minutes at $700 \times \mathrm{g}$, and before eliminating the crude nuclei, the supernatant was centrifuged 10 minutes at $15,000 \times \mathrm{g}$. The precipitate (crude mitochondrial fraction) was discarded and the supernatant centrifuged at $105,000 \times \mathrm{g}$ for 60 minutes. The crude microsomal fraction resultant was re-suspended in KCL $125 \mathrm{mM}$ (1 $\mathrm{ml}$ of solution/g of liver used for the preparation) for a concentration of $12.0 \mathrm{mg}$ of microsomal protein $/ \mathrm{mL}$ ).

Microsomal Peroxidation. The induction of lipid peroxidation on microsomal membranes was carried out with a controlled system described previously [37,38] and with a reaction mix containing $20 \mathrm{mM}$ nicotinamide, $2 \mathrm{mM}$ ADP, $0.12 \mathrm{mM} \mathrm{FeCl}_{3}$, and $0.4 \mathrm{mM}$ $\mathrm{NADPH}$ in a $80 \mathrm{mM} \mathrm{KCl}$ solution. The control samples without peroxidation were prepared as previously described but without the addition of NADPH (Figure 3, MICROSOMES NO PEROXIDATION). In the experimental procedure to inhibit lipid peroxidation by blocking the carbonyl groups, sodium bisulfite $(0.01$ $\mu \mathrm{M})$ was added to the reaction mix at the end of the incubation time $(1 \mathrm{~h})$. The $\mathrm{pH}$ of the samples had been previously neutralized.

\section{Protein Carbonyl Measurement}

Protein carbonyl determination was carried out in accordance with previous reports [39]. Protein samples containing $6 \mathrm{mg} / \mathrm{ml}$ of protein were re-suspended in 1 $\mathrm{ml}$ of $10 \mathrm{mM} \mathrm{2,4-dinitrophenylhydrazine} \mathrm{(DNPH)} \mathrm{in} 2$ $\mathrm{M} \mathrm{HCl}$. The samples were incubated at laboratory 
temperature in the dark for $60 \mathrm{~min}$, stirring at 15-minute intervals. The samples that had been previously precipitated with trichloroacetic acid (20\%), centrifuged at $11,000 \times \mathrm{g}$ for 10 minutes and re-suspended with a pulse of sonication, were washed three times with $1 \mathrm{~mL}$ of ethanol-ethyl acetate $(1: 1 ; \mathrm{v} / \mathrm{v})$ to remove the residual DNPH reagent. The final precipitates were dissolved in $6 \mathrm{~N}$ guanidine hydrochloride solution $(1 \mathrm{~mL})$. The protein carbonyl content was determined by measuring the absorbance of the protein-2, 4 dinitrophenylhydrazone derivatives at $375 \mathrm{~nm}$, using a molar absorption coefficient of $22,000 \mathrm{M}^{-1} \mathrm{~cm}^{-1}$.

\section{Statistical Analysis}

Results were expressed as mean \pm standard deviation (SD). Groups were compared using one way ANOVA test followed by Dunet's test.

\section{Additional material}

\section{Additional file 1: Aldehyde condensation from unsaturated fatty} acids and in absence of proteins. Unsaturated aldehydes from the free fatty acid (FFA) lipid peroxidation can be condensed at alkaline $\mathrm{pH}$ and produce a strong absorbance at $266 \mathrm{~nm}$. Ferric ions ( $\mathrm{Fe}$ ) and glucose (GLU) autoxidation catalyzed by traces of transition metals are the most probable source of lipid peroxidation (references 23 and 24) and aldehyde production in a time dependent slow rate (24 hours) reaction. The maximal aldol-protein production was obtained with the additive effect of GLU and ferric ions (FFAs + Glu + $\mathrm{Fe}^{3+}$ ), but even with the use of a nitrogen environment some amount of autoxidation of FFAs generates unsaturated aldehydes and aldolic condensation such as can be observed in the left short bar.

Additional file 2: Validated carbonyl proteins introduction to the serum samples derived from aldehyde capture. The differences in carbonyl content of the serum samples before and after aldehyde capture treatment were corroborated. The results demonstrated the incorporation of the carbonyl groups to the serum proteins and aldolprotein formation from aldehyde capture $(p=0.002)$. Only the samples of patients with diabetic nephropathy and higher level of aldol proteins presented at the same time higher levels of protein carbonyls. Results and samples correspond to the data presented in the text in Table 1.

\section{Acknowledgements}

This study was supported by a grant from the Fondo de Investigación en Salud FIS/IMSS/PROT/G10/854 and a grant from Consejo Nacional de Ciencia y Tecnología (CONACYT) SALUD-2010-01-141937 FIS/IMSS/PROT/896

\section{Author details}

'Department of Experimental Metabolism. Center for Biomedical Research of Michoacán (CIBIMI-IMSS), Michoacán, México. ${ }^{2}$ Department of Research in Clinical Epidemiology. Center for Biomedical Research of Michoacán (CIBIMIIMSS), Michoacán, México. ${ }^{3}$ Postgraduate Studies Division, Faculty of Odontology. University of Michoacán (Universidad Michoacana de San Nicolás de Hidalgo, UMSNH), Michoacán, México.

\section{Authors' contributions}

RMN conceived, designed and coordinated the work, as well as prepared the manuscript. RNA participated in the co-design of the work as well as the draft of the manuscript. CAA carried out analytical and statistical analysis and participated in the co-design of the work. All authors read and approved the final manuscript.

\section{Competing interests}

The authors declare that they have no competing interests.

Received: 30 September 2011 Accepted: 7 November 2011 Published: 7 November 2011

\section{References}

1. Grune T, Reinheckel T, Davies KJ: Degradation of oxidized proteins in mammalian cells. FASEB J 1997, 11:526-534.

2. Dean RT, Fu S, Stocker R, Davies MJ: Biochemistry and pathology of radical-mediated protein oxidation. Biochem J 1997, 324:1-18.

3. Reznick $A Z$, Packer L: Oxidative damage to proteins: spectrophotometric method for carbonyl assay. Methods Enzymol 1994, 233:357-363.

4. Stadtman ER, Starke-Reed PE, Oliver CN, Carney JM, Floyd RA: Protein modification in aging. EXS 1992, 62:64-72.

5. Stadtman ER: Protein oxidation and aging. Science 1992, 257:1220-1224.

6. Levine RL, Williams JA, Stadtman ER, Shacter E: Carbonyl assays for determination of oxidatively modified proteins. Methods Enzymol 1994, 233:346-357.

7. Levine RL, Wehr N, Williams JA, Stadtman ER, Shacter E: Determination of carbonyl groups in oxidized proteins. Methods Mol Biol 2000, 99:15-24.

8. Stadtman ER, Oliver CN: Metal-catalyzed oxidation of proteins. Physiological consequences. J Biol Chem 1991, 266:2005-2008.

9. Leeuwenburgh C, Hansen P, Shaish A, Holloszy JO, Heinecke JW: Markers of protein oxidation by hydroxyl radical and reactive nitrogen species in tissues of aging rats. Am J Physiol 1998, 274:R453-R461.

10. Hazell $L$, van den Berg JJ, Stocker R: Oxidation of low-density lipoprotein by hypochlorite causes aggregation that is mediated by modification of lysine residues rather than lipid oxidation. Biochem J 1994, 302:297-304.

11. Cross CE, Reznick AZ, Packer L, Davis PA, Suzuki YJ, Halliwell B: Oxidative damage to human plasma proteins by ozone. Free Radic Res Commun 1992, 15:347-352.

12. Halliwell B, Gutteridge JM: Free Radicals in Biology and Medicine. Clarendon Press, Oxford, USA; 42007

13. Burcham PC, Kuhan YT: Introduction of carbonyl groups into proteins by the lipid peroxidation product, malondialdehyde. Biochem Biophys Res Commun 1996, 220:996-1001

14. Blakeman DP, Ryan TP, Jolly RA, Petry TW: Diquat-dependent protein carbonyl formation. Identification of lipid-dependent and lipidindependent pathways. Biochem Pharmacol 1995, 50:929-935.

15. Miyata T, van Ypersele de Strihou C, Kurokawa K, Baynes JW: Alterations in nonenzymatic biochemistry in uremia: origin and significance of "carbonyl stress" in long-term uremic complications. Kidney Int 1999, 55:389-399.

16. Miyata T, Izuhara Y, Sakai H, Kurokawa K: Carbonyl stress: increased carbonyl modification of tissue and cellular proteins in uremia. Perit Dial Int 1999, 19:S58-S61.

17. Miyata T, Wada Y, Cai Z, lida Y, Horie K, Yasuda Y, Maeda K, Kurokawa K, van Ypersele de Strihou C: Implication of an increased oxidative stress in the formation of advanced glycation end products in patients with endstage renal failure. Kidney Int 1997, 51:1170-1181.

18. Holt S, Moore K: Pathogenesis of renal failure in rhabdomyolysis: the role of myoglobin. Exp Nephrol 2000, 8:72-76.

19. Holt S, Reeder B, Wilson M, Harvey S, Morrow JD, Roberts LJ, Moore K: Increased lipid peroxidation in patients with rhabdomyolysis. Lancet 1999, 353:1241.

20. Esterbauer H, Schaur RJ, Zollner H: Chemistry and biochemistry of 4hydroxynonenal, malonaldehyde and related aldehydes. Free Radic Biol Med 1991, 11:81-128.

21. LoPachin RM, Gavin T, Geohagen BC, Das S: Neurotoxic mechanisms of electrophilic type-2 alkenes: soft interactions described by quantum mechanical parameters. Toxicol Sci 2007, 98:561-570

22. LoPachin RM, Barber DS, Gavin T: Molecular mechanisms of the conjugated alpha, beta-unsaturated carbonyl derivatives: relevance to neurotoxicity and neurodegenerative diseases. Toxicol Sci 2008, 104:235-249.

23. Medina-Navarro R, Duran-Reyes G, Diaz-Flores M, Hicks JJ, Kumate J: Glucose-stimulated acrolein production from unsaturated fatty acids. Hum Exp Toxicol 2004, 23:101-105. 
24. Medina-Navarro R, Durán-Reyes G, Díaz-Flores M, Kumate J, Hicks JJ: Glucose autoxidation produce acrolein from lipid peroxidation in vitro. Clin Chim Acta 2003, 337:183-185.

25. Cockcroft DW, Gault MH: Prediction of creatinine clearance from serum creatinine. Nephron 1976, 16:31-41.

26. Requena JR, Fu MX, Ahmed MU, Jenkins AJ, Lyons TJ, Baynes JW, Thorpe SR: Quantification of malondialdehyde and 4-hydroxynonenal adducts to lysine residues in native and oxidized human low-density lipoprotein. Biochem J 1997, 322:317-325.

27. Halliwell B, Chirico S: Lipid peroxidation: its mechanism measurement, and significance. Am J Clin Nutr 1993, 57:715S-724S.

28. Moore K, Roberts $\mathrm{L}$ : Measurement of lipid peroxidation. Free Radic Res 1998, 28:659-671.

29. Michel F, Bonnefont-Rousselot D, Mas E, Drai J, Thérond P: Biomarkers of lipid peroxidation: analytical aspects. Ann Biol Clin 2008, 66:605-620.

30. Zoccali C, Mallamaci F, Tripepi G: AGEs and carbonyl stress: potential pathogenetic factors of long-term uraemic complications. Nephrol Dial Transplant 2000, 15:7-11.

31. Miyata T, Fu MX, Kurokawa K, van Ypersele de Strihou C, Thorpe SR, Baynes JW: Products of autoxidation of both carbohydrates and lipids are increased in uremic plasma: evidence for a generalized increase in oxidative stress in uremia? Kidney Int 2000, 54:1290-1295.

32. Miyata T, Ueda Y, Yamada Y, Izuhara Y, Wada T, Jadoul M, Saito A, Kurokawa K, van Ypersele de Strihou C: Accumulation of carbonyls accelerates the formation of pentosidine, an advanced glycation end product: carbonyl stress in uremia. Am Soc Nephrol 1998, 9:2349-2356.

33. Better OS, Stein JH: Early management of shock and prophylaxis of acute renal failure in traumatic rhabdomyolysis. N Engl J Med 1990, 322:825-829.

34. Zager RA: Studies of mechanisms and protective maneuvers in myoglobinuric acute renal injury. Lab Invest 1989, 60:619-629.

35. Rodríguez-Malaver AJ, Leake DS, Rice-Evans CA: The effects of $\mathrm{pH}$ on the oxidation of low-density lipoprotein by copper and metmyoglobin are different. FEBS Lett 1997, 406:37-41.

36. Moore KP, Holt SG, Patel RP, Svistunenko DA, Zackert W, Goodier D, Reeder BJ, Clozel M, Anand R, Cooper CE, Morrow JD, Wilson MT, Roberts $\mathrm{L}$ : A causative role for redox cycling of myoglobin and its inhibition by alkalinization in the pathogenesis and treatment of rhabdomyolysis-induced renal failure. J Biol Chem 1998, 273:31731-31737.

37. Wills ED: Lipid peroxide formation in microsomes. General considerations. Biochem J 1996, 113:315-324.

38. Hicks JJ, Medina-Navarro R: Inhibitory capacity of human serum on induced microsomal lipoperoxidation. Arch Med Res 1995, 26:169-172.

39. Levine RL: Carbonyl modified proteins in cellular regulation, aging, and disease. Free Radic Biol 2002, 32:790-796.

\section{doi:10.1186/1476-511X-10-201}

Cite this article as: Medina-Navarro et al:: Protein conjugated with aldehydes derived from lipid peroxidation as an independent parameter of the carbonyl stress in the kidney damage. Lipids in Health and Disease 2011 10:201.

\section{Submit your next manuscript to BioMed Central and take full advantage of:}

- Convenient online submission

- Thorough peer review

- No space constraints or color figure charges

- Immediate publication on acceptance

- Inclusion in PubMed, CAS, Scopus and Google Scholar

- Research which is freely available for redistribution 